\title{
TANGGUNG JAWAB DEVELOPER TERHADAP KONSUMEN AKIBAT WANPRESTASI DALAM PENYERAHAN UNIT APARTEMEN PLUIT SEA VIEW BERDASARKAN PERJANJIAN PENGIKATAN JUAL BELI
}

\author{
Natalia Salim \\ (Mahasiswa Program S1 Fakultas Hukum Universitas Tarumanegara) \\ (E-mail: liiyalimz@gmail.com)
}

\begin{abstract}
Dr. Endang Pandamdari, S.H., C.N. M.H.
(Dosen Hukum Perdata Fakultas Hukum Universitas Tarumanagara. Meraih Sarjana Hukum (S.H.) dan Universitas Indonesia, Magister Hukum (M.H) dari Universitas Indonesia, meraih Doktor Hukum (Dr.) dari Universitas Trisakti)

(E-mail: epandamdari@yahoo.com)
\end{abstract}

\begin{abstract}
Abstrak
The procurement of an apartment is strengthened by Sales and Purchase Agreement (PPJB) between the buyer and the developer, but the practice in the field are often found that developers does not handover the physical terms in accordance with the agreed time (default/breach of contract), and resulting in losses for the buyer. This study aims to determine the responsibility of the developer to the buyer due to default/breach pf contract matter and legal protection for the buyer in terms of buying Pluit Sea View apartments based on Sale and Purchase agreement. Research data were analyzed using descriptive-qualitative analysis methods which were tested with legal norms. The result of analysis shows that: 1. PT. Binakarya Bangun Propertindo (as developer) does not fulfill their responsibilities as in agreement of the PPJB regarding the rights of consumers. 2. Weak of Consumer Protection Sarusun Belonging to Pluit View Sea, as consumer do not have bargaining positions.
\end{abstract}

Keyword: Default of contract, Consumer Protection, the responsibility of the developer

\section{PENDAHULUAN}

\section{A. Latar Belakang}

Hunian tempat tinggal adalah kebutuhan primer bagi manusia. Rumah berfungsi sebagai tempat aktivitas utama manusia. Rumah juga berfungsi sebagai tempat tinggal, pelindung dari cuaca, gangguan binatang buas, dan area privat bagi manusia. Pesatnya pertambahan jumlah penduduk setiap tahunnya mengakibatkan kebutuhan rumah mengalami peningkatan dan berakibat makin sempitnya lahan yang dibangun karenanya harga tanah semakin mahal. Keadaan ini 
Natalia Salim \& Endang Pandamdari TANGGUNG JAWAB DEVELOPER TERHADAP KONSUMEN AKIBAT WANPRESTASI DALAM PENYERAHAN UNIT APARTEMEN PLUIT SEA VIEW BERDASARKAN PERJANJIAN PENGIKATAN JUAL BELI

Volume 2 Nomor 2, Desember 2019

E-ISSN : 2655-7347

memunculkan kebijakan yang berasal dari pemikiran pemanfaatan lahan semaksimalnya dan melahirkan konsep pembangunan bangunan secara vertikal yang dapat difungsikan sebagai tempat perdagangan, perkantoran dan perumahan yang disebut dengan apartemen atau rumah susun.

Penyediaan perumahan dalam skala besar seperti skala nasional memerlukan peran serta banyak pihak selain pemerintah, yaitu pihak swasta seperti pengusaha property/real estateatau biasa disebut dengan developer, masyarakat dan lembaga lain yang terkait. Kebutuhan masyarakat akan tempat tinggal, dapat dipenuhi dengan membuat rumah sendiri bisa juga dengan membeli rumah yang disediakan oleh perusahaan developer. Saat ini sudah banyak developer yang menawarkan berbagai tipe dan jenis hunian, seperti perumahan, apartemen atau rumah susun. Pada umumnya masyarakat di daerah perkotaan seperti Jakarta, lebih memilih untuk membeli perumahan atau apartemen dari suatu developer. Berdasarkan Undang-Undang Republik Indonesia Nomor 20 Tahun 2011 tentang Rumah Susun Pasal 1 angka 15, Developer ialah setiap orang dan/atau pemerintah yang melakukan pembangunan perumahan dan pemukiman. Pasal 5 ayat (1) Permendagri No. 5 Tahun 1974 tentang Ketentuan-ketentuan Mengenai Penyediaan dan Pemberian Tanah untuk Keperluan Perusahaan yang menyebutkan bahwa perusahaan pembangunan perumahan ialah sebuah perusahaan yang memiliki usaha di bidang pembangunan perumahan dari berbagai jenis dalam jumlah yang besar diatas suatu areal tanah yang merupakan satu kesatuan lingkungan pemukiman dilengkapi dengan sarana prasarana dan fasilitas sosial yang dibutuhkan masyarakat penghuninya.

Apartemen dibangun dengan tujuan untuk mewujudkan hunian yang layak dengan harga terjangkau dalam lingkungan yang sehat, aman, nyaman dan berkesinambungan serta menciptakan satu pemukiman terpadu dalam rangka membangun pertahanan ekonomi, sosial dan budaya. Apartemen berfungsi untuk meningkatkan efisiensi dan 
Volume 2 Nomor 2, Desember 2019

E-ISSN : 2655-7347

efektivitas pemanfaatan ruang dan tanah, juga menyediakan ruang terbuka hijau di wilayah kota.

Pada saat seseorang melakukan pembelian rumah atau apartemen kepada developer maka di antara keduanya terjalin suatu hubungan. Hubungan seseorang dengan sebuah lembaga dalam jual beli biasanya terikat dalam suatu ikatan yang disebut perjanjian. Perjanjian ialah suatu tindakan dimana seorang atau lebih mengikatkan diri dengan seorang atau lebih.

Ada beberapa bentuk perjanjian yang banyak dipakai dalam masyarakat salah satunya mengenai perjanjian jual beli properti yang mana bentuk perjanjiannya melibatkan dua fihak yakni penjual dan pembeli dimana penjual berkewajiban untuk menyerahkan barang berupa apartemen tepat pada waktunya dan pembeli berkewajiban untuk membayar properti sesuai kesepakatan dalam perjanjian. Pasal 1457 KUHPerdata menegaskan jual beli sebagai suatu perjanjian yang mana pihak satu mengikatkan diri untuk memberi suatu kebendaan dan pihak yang satunya membayar harga yang sudah dijanjikan. Penjual berjanji memberikan kepemilikan barang yang dijual dan pembeli menjanjikan membayar harga yang disetujuinya. Lebih lanjut disebutkan walau undang-undang tidak menyebut harga diharuskan dalam bentuk sejumlah uang, karena apabila bukan uang maka tidak disebut jual beli namun tukar menukar. ${ }^{1)}$

Pada hakikatnya semua pihak yang melakukan perjanjian memiliki itikad baik. Tetapi dalam perjalanannya, tidak jarang timbul wanprestasi dari salah satu pihak dalam perjanjian. Subekti mendefinisikan wanprestasi sebagai tindakan debitur yang tidak memenuhi janjinya dalam perjanjian atau melanggar perjanjian dengan melakukan apa-apa yang tidak boleh dilakukan, atau alpa, lalai atau mengingkari jani. ${ }^{2)}$ Pasal 1234 KUHPerdata menyebutkan yang dimaksud prestasi ialah untuk

\footnotetext{
1) I Ketut Oka Setiawan, Hukum Perikatan, (Jakarta: Sinar Grafika, 2016), hal. 158.
}

${ }^{2)}$ R. Subekti, Hukum Perjanjian, (Jakarta: PT Intermasa, 2008), hal. 45 
Volume 2 Nomor 2, Desember 2019

E-ISSN : 2655-7347

memberikan seswatu, untuk berbuat seswatu, atau untuk tak berbuat seswatu, sebaliknya seorang dinilai wanprestasi jika:

1. Tidak melaksanakan yang disanggupi untuk dilaksanakan;

2. Melaksarakan yang dipejanjikan tetapi tidak seperti yang dijanjikan;

3. MeIaksanakan yang diperjarjikan tapi terlambat;

4. Melakukan sessuatu yang tidak diperbolehkan dalam perjanjian.

Banyak fakta menunjukkan adanya kasus wanprestasi oleh developer. Misalnya kasus wanprestasi PT. Binakarya Bangun Propertindo kepada konsumennya yang membeli 1 unit apartemen di Apartemen Pluit Sea View. Salah seorang pembeli yang namanya tidak ingin disebutkan mengaku telah membeli Apartemen Pluit Sea View dari PT Binakarya Bangun Propertindo dan dijanjikan akan dilakukan serah terima pada bulan Januari 2016, tetapi nyatanya sampai dengan waktu yang telah ditentukan, developer belum juga menyerahkan unit apartemen. Kemudian pada tanggal 6 April 2017, pembeli mengajukan klaim keterlambatan serah terima sesuai perjanjian yang ada dalam PPJB 188/PPJB_PSV/BBP/VI/2014. Namun sampai penelitian ini ditulis, klaim masih belum dibayarkan. Pembeli ini mengharapkan itikad baik dari PT Binakarya Bangun Propertindo selaku pengembang Apartemen Pluit Sea View untuk segera menyelesaikan permasalahan. ${ }^{3)}$

Penyerahkan fisik Apartemen Pluit Sea View sesuai PPJB kepada konsumen merupakan tanggung jawab dari developer. Tidak terpenuhinya kewajiban atau tanggung jawab developer tersebut merupakan tindakan wanprestasi yang dilakukan oleh developer PT.

${ }^{3)}$ Andi_Wijaya, 2017. Sudah Lewat Waktunya, Apartemen Pluit Sea View belum Serah Terima, Senin 10 Juli 2017. https://news.detik.com/suara-pembaca/3553807/ sudah-lewat-waktunyaapartemen-pluit-sea-view-belum-serah-terima, diakses tanggal 7 November 2019. 
Volume 2 Nomor 2, Desember 2019

E-ISSN : 2655-7347

Binakarya Bangun Propertindo dan telah mengakibatkan kerugian kepada konsumennya.

Wanprestasi yang dilakukan oleh developer merugikan konsumen utamanya dibidang perumahan, karenanya penting untuk mengetahui berbagai aspek terkait tanggung jawab developer agar dapat mengupayakan perlindungan konsumen dibidang property. Oleh karena itu, peneliti merasa perlu untuk melakukan penelitian yang mengkaji tanggung jawab developer dalam perjanjian jual beli apartemen dengan judul: TANGGUNG JAWAB DEVELOPER TERHADAP KONSUMEN AKIBAT WANPRESTASI DALAM PENYERAHAN UNIT APARTEMEN PLUIT SEA VIEW BERDASARKAN PERJANJIAN PENGIKATAN JUAL BELI.

\section{B. Perumusan Masalah}

Berdasar latar belakang yang telah diuraikan diatas, dirumuskan permasalhan dalam penelitina ini yaitu:

1. Bagaimana tanggung jawab developer terhadap konsumen akibat wanprestasi dalam penyerahan unit Apartemen Pluit Sea View berdasarkan Perjanjian Pengikatan Jual Beli?

2. Bagaimana prelindungan hokum terhadap konsumen dalam hal pembelian Apartemen Pluit Sea View berdasarkan Perjanjian Pengikatan Jual Beli?

\section{Metode Penelitian}

1. Pendekatan penelitian

Penelitian hukum merupakan satu proses yang dilakukan untuk menentukan aturan hukum, aturan-aturan hukum maupun doktrindoktrin hukum dengan tujuan untuk menjawab isu hukum yang dihadapi. ${ }^{4}$

\footnotetext{
4)Ibid,hal.. 141.
} 
Oleh karena itu, dalam penelitian ini metode yang digunakan adalah metode hukum secara normatif (yuridis normatif) yang dilakukan dengan cara meneliti bahan putsaka yang merupakan data sekunder yang terdir idari bahan hukum primer dan bahan hukum sekunder.

\section{Sifat Penelitian}

Penelitian ini bersifat deskriptif, yaitu penelitian yang memberikan penjelasan data dengan sangat teliti mengenai manusia, keadaan atas gejala- gejala lain dan maksud dari penelitian. Penulis menggunakan penelitian deskriptif, karena ingin menjelaskan sejelas mungkin mengenai hak dan kewajiban para pihak yang melakukan perjanjian, akibat hukum dan upaya penyelesaian developer yang wanprestasi.

\section{Jenis Data}

Sumber dan jenis data yang dipakai untuk penelitian ini adalah data sekunder. Data sekunder merupakan data yang diperoleh dengan cara studi kepustakaan dan dokumenter serta surat Perjanjian Jual Beli Apartemen Pluit Sea View.

Di samping data sekunder digunakan juga data tersier yakni data yang dapat memberikan petunjuk atau penjelasan terhadap bahan hukum primer dan bahan hukum sekunder. Misalnay bahan atau artikel dari kamus, internet, ensikopedia dan indeks komulatif yang berhubungan dengan permasalahan yang dikaji dalam penelitian sebagai bahan pelengkap yang berkaitan dengan teori yang digunakan. Selain itu juga digunakan data tersier atau penunjang. Penelitian ini menggunakan data atau bahan yang memberikan petunjuk maupun penjelasan terhadap bahan hukum primer dan bahan hukum sekunder, missal nya bahan dari media internet, kamus, ensiklopedia dan indeks kumulatif yang ada hubungannya dengan penelitian sebagai bahan pelengkap yang berkaitan dengan teori- teori yang ada.

4. Teknik Pengumpulan Data 
Volume 2 Nomor 2, Desember 2019

E-ISSN : 2655-7347

Teknik pengumpulaan data untuk mendapatkan data yang digunakan dalam penelitian skripsi ini adalah menggunakan studi pustaka untuk memperoleh data primer, data sekunder, dan data tersier yaitu melakukan serangkaain kegiatan studi dokumentasi, dengan cara membaca, dan menguitp buku-buku atau referensi yang berhubungan dengan permasalahan yang dikaji dalam skripsi ini.

\section{PEMBAHASAN}

\section{A. Kasus}

Kasus pengembang yang bermasalah masih saja terjadi sampai saat ini, seperti halnya pada pengembang PT Binakarya Bangun Propertindo yang merupakan developer yang membangun Apartemen Pluit Sea View sebanyak 5 tower. Pengembang PT Binakarya Bangun Propertindo tidak kunjung menyelesaikan apartemen yang dibangunnya sehingga merugikan konsumennya. Banyak pembeli yang sudah memenuhi kewajibannya yaitu membayar lunas apartemen yang dipesannya kepada pembeli, namun pihak pengembang tidak kunjung menyelesaikan pembangunannya.

Salah seorang pembeli yang namanya tidak ingin disebutkan mengaku telah membeli Apartemen Pluit Sea View dari PT Binakarya Bangun Propertindo dan dijanjikan akan dilakukan serah terima pada bulan Januari 2016, tetapi nyatanya sampai dengan waktu yang telah ditentukan, developer belum juga menyerahkan unit apartemen. Kemudian pada tanggal 6 April 2017, pembeli mengajukan klaim keterlambatan serah terima sesuai perjanjian yang ada dalam PPJB 188/PPJB_PSV/BBP/VI/2014. Namun sampai surat ini ditulis, klaim masih belum dibayarkan. Pembeli ini mengharapkan itikad baik dari PT 
Volume 2 Nomor 2, Desember 2019

E-ISSN : 2655-7347

Binakarya Bangun Propertindo selaku pengembang Apartemen Pluit Sea View untuk segera menyelesaikan permasalahan. ${ }^{5)}$

Disamping itu juga ada kasus lain yang sudah diselesaikan melalui pengadilan, yaitu kasus Putusan Nomor 102/Pdt.Sus.PKPU/2019/PN.Jkt.Pst. Putusan ini adalah putusan tentang perkara yang diakibatkan oleh adanya perjanjian jual beli yang diadakan oleh konsumen yang bernama $\mathrm{Ng}$ Hui Hui dengan developer yaitu PT. Binakarya Bangun Propertindo untuk pembelian 1 unit apartemen di Apartemen Pluit Sea View. Dalam perjanjian disebutkan bahwa pihak konsumen melakukan pembayaran satu unit rumah susun Pluit Sea View Tower Ibiza B lantai 15 nomor 06 type 2 BR $42 \mathrm{~m} 2$ senilai Rp431.200.000 kepada developer yaitu PT. Binakarya Bangun Propertindo, dan developer akan melakukan penyerahan fisik atas unit Apartemen Sea View pada 30 April 2016.

Pada kenyataannya developer tidak melakukan penyerahan fisik sesuai dengan waktu yang telah diperjanjikan (wanprestasi), padahal $\mathrm{Ng}$ Hui Hui sudah melunasi pembayaran satu unit apartemen tersebut. Bahkan sampai batas toleransi waktu perpanjangan yang sudah disepakati dalam PPJB, pihak developer belum dapat memenuhi kewajibannya yang telah jatuh tempo yaitu serah terima fisik Satuan Rumah Susun Pluit Sea View kepada pembeli. Atas perkara ini developer telah merugikan konsumen dan harus memberikan kompensasi berupa pemberian ganti rugi sesuai dengan yang tertuang dalam PPJB, namun karena sampai jatuh tempo developer juga tidak mampu memenuhi kewajiban tersebut maka konsumen mengajukan perkara ini ke pengadilan. PT. Binakarya Bangun Propertindo selaku developer dalam Putusan pengadilan negeri dinyatakan pailit.

${ }^{5)}$ Andi_Wijaya, 2017. Sudah Lewat Waktunya, Apartemen Pluit Sea View belum Serah Terima, Senin 10 Juli 2017. https://news.detik.com/suara-pembaca/3553807/ sudah-lewat-waktunyaapartemen-pluit-sea-view-belum-serah-terima, diakses tanggal 7 November 2019. 
Hasil Putusan Nomor 102/Pdt.Sus.PKPU/2019/PN.Jkt.Pst. menyatakan sah perdamaian yang dilakukan antara $\mathrm{Ng}$ Hui Hui dengan PT. Binakarya Bangun Propertindo sebagaimana yang disepakati oleh kedua belah pihak pada tanggal 25 Juli 2019. Pada Putusan Nomor 102/Pdt.Sus.PKPU/2019/PN. Niaga.Jkt.Pst. termuat juga pasal-pasal perdamaian yang dilakukan oleh kedua belah pihak, namun pada intinya adalah pemberian waktu kepada developer untuk menyelesaikan pembangunan apartemennya dan memastikan melakukan penyerahan fisik sesuai dengan waktu yang telah diperjanjikan dalam perdamaian.

\section{B. Tanggungjawab Developer Akibat Wanprestasi terhadap}

\section{Konsumen}

Perjanjian yang dibuat antara lain berupa perjanjian jual beli yang dikaji dalam penelitian ini. Perjanjian jual beli dilakukan oleh dua pihak, yaitu pihak pertama sebagai pihak penjual dan pihak kedua sebagai pihak pembeli. Kedua belah pihak melakukan suatu perbuatan yang disebut dengan penjualan dan pembelian. Pihak pertama selaku penjual menjual barangnya, sedangkan pihak kedua selaku pembeli memberi barang dari penjual. Dalam penelitian ini pihak pertama adalah PT. Binakarya Bangun Propertindo (developer) sebagai penjual Apartemen Pluit Sea View, dan pihak kedua adalah konsumen yang membeli Apartemen Pluit Sea View.

Jual beli Apartemen Pluit Sea View PT. Binakarya Bangun Propertindo (developer) dengan konsumen dikuatkan dengan suatu perjanjian jual beli. Perjanjian jual beli ini harus dilaksanakan dengan itikad baik oleh kedua belah pihak yang melakukan perjanjian termasuk segala hal yang telah disepakati dalam perjanjian tersebut. Sesuai Pasal 1338 KUHPerdata ayat (3) yaitu bahwa suatu perjanjian harus dilaksanakan dengan itikad baik. 
Itikad baik dalam perjanjian jual beli Apartemen Pluit Sea View antara PT. Binakarya Bangun Propertindo (developer) dengan konsumen adalah ditunjukkan dengan cara masing-masing pihak memenuhi hak dan kewajibannya seperti yang disepakati dalam perjanjian jual beli tersebut. Dalam perjanjian jual beli Apartemen Pluit Sea View disebutkan hak dan kewajiban PT. Binakarya Bangun Propertindo (developer) dengan konsumen, yaitu:

1. Hak dan kewajiban pihak pertama

a. Hak pihak pertama

1) mendapatkan pembayaran dari pihak kedua sesuai dengan harga pengikatan dan jangka waktu yang ditetapkan dalam perjanjian,

2) memberikan peringatan kepada pihak kedua apabila belum memenuhi kewajibannya sesuai yang tertera dalam perjanjian,

3) memberikan sanksi atau denda kepada pihak kedua apabila lalai dengan kewajibannya.

b. Kewajiban pihak pertama

1) membangun sarusun menurut gambar denah yang ada dalam perjanjian,

2) menyerahkan secara fisik bangunan sarusun Pluit Sea View sesuai dengan waktu yang telah ditetapkan dalam perjanjian,

3) membayar biaya Pajak Pertambahan Nilai (PPN), Ijin Mendirikan Bangunan (IMB) induk, pemasangan instalasi air dan pemasangan instalasi listrik (untuk 1 kamar sebesar 900 watt dan untuk 2 dan 3 kamar sebesar 1.300 watt),

4) membuat berita acara serah terima sarusun Pluit Sea View,

5) bertanggung jawab terhadap segala akibat karena kesalahan konstruksi atas tanah dan bangunan dengan memperbaikinya selama 30 hari. 
2. Hak dan Kewajiban Pihak Kedua

a. Hak pihak kedua

1) menerima secara fisik bangunan sarusun Pluit Sea View sesuai dengan waktu yang telah ditetapkan dalam perjanjian,

2) mendapat berita acara serah terima bangunan sarusun Pluit Sea View,

3) mendapat garansi bangunan sarusun Pluit Sea View sesuai yang ditetapkan dalam perjanjian,

4) menerima ganti rugi akibat kelalaian yang dilakukan oleh pihak pertama,

5) menempuh jalur hukum bila pihak pertama melanggar perjanjian atau tidak memenuhi kewajibannya sesuai yang ditetapkan dalam perjanjian,

6) mendapat perlindungan hukum apabila terjadi sengketa.

b. Kewajiban pihak kedua

1) membayar lunas harga pengikatan sarusun Pluit Sea View dan biaya-biaya lain sesuai yang ditetapkan dalam perjanjian perjanjian

2) bersama dengan pihak pertama menandatangani berita acara serah terima sarusun Pluit Sea View apabila sudah diserahterimakan kepada pihak kedua,

3) wajib menggunakan sarusun Pluit Sea View sesuai dengan peruntukannya sebagaimana yang ditentukan oleh instansi yang berwenang,

4) sejak tanggal dilakukan serah terima maka pihak kedua menanggung semua biaya dan iuran yang berkaitan dengan Sarusun Milik. 
Pihak penjual dan pembeli sama-sama harus memiliki itikad baik dengan memenuhi hak dan kewajibannya masing-masing sesuai dengan yang sudah disepakati dalam perjanjian jual beli. Hal ini sebagaimana pendapat yang dikemukakan oleh Handri Raharjo yaitu bahwa perjanjian adalah suatu hubungan hukum di bidang harta kekayaan yang didasari kata sepakat antara subjek hukum yang satu dengan yang lain, dan di antara mereka (para pihak/subjek hukum) saling mengikatkan dirinya sehingga subjek hukum yang satu berhak atas prestasi dan subjek hukum yang lain berkewajiban melaksanakan prestasinya sesuai dengan kesepakatan yang telah disepakati para pihak tersebut serta menimbulkan akibat hukum. ${ }^{6}$ )

Terkait dengan perjanjian jual beli Sarusun Milik Pluit Sea View antara PT. Binakarya Bangun Propertindo (developer) dengan konsumen, pada intinya PT. Binakarya Bangun Propertindo (developer) memiliki hak untuk mendapatkan pembayaran penuh dari konsumen sesuai dengan harga yang tercantum dalam perjanjian dan memiliki kewajiban untuk menyerahkan bangunan Apartemen Pluit Sea View sesuai spesifikasi konstruksi yang ada dalam perjanjian dalam waktu yang disepakati. Konsumen memiliki hak untuk menerima Apartemen Pluit Sea View sesuai yang ada dalam perjanjian dan berkewajiban untuk membayar penuh Apartemen seharga yang tercantum dalam perjanjian.

Suatu perjanjian jual beli akan berjalan baik-baik saja sepanjang tidak ada masalah di dalamnya. Perjanjian menjadi bermasalah apabila salah satu pihak melanggar perjanjian yaitu tidak memenuhi prestasi atau kewajibannya yang merupakan hak pihak lain, atau biasa disebut dengan melakukan wanprestasi. Menurut Pasal 1234 KUHPerdata seseorang dianggap melakukan wanprestasi apabila:

\footnotetext{
${ }^{6}$ Handri Raharjo. Hukum Perjanjian di Indonesia. (Yogyakarta: Pustaka Yustisia, 2009), hal. 42.
} 
1. Tidak melaksanakan yang disanggupi untuk dilaksanakan;

2. Melaksanakan yang diperjanjikan tetapi tidak seperti yang dijanjikan;

3. Melaksanakan yang diperjanjikan tapi terlambat;

4. Melakukan sesuatu yang tidak diperbolehkan dalam perjanjian.

Pada kasus perjanjian jual beli Apartemen Pluit Sea View yang melakukan wanprestasi adalah penjual sekaligus developer (PT. Binakarya Bangun Propertindo). Developer dianggap telah melakukan wanprestasi karena tidak melakukan apa yang disanggupi akan dilakukannya. Developer tidak melakukan penyerahan fisik sesuai dengan waktu yang telah diperjanjikan (wanprestasi), padahal konsumen sudah melunasi pembayaran satu unit Apartemen sesuai harga yang disepakati dalam perjanjian. Bahkan sampai batas toleransi waktu perpanjangan yang sudah disepakati dalam PPJB, pihak developer belum dapat memenuhi kewajibannya yang telah jatuh tempo yaitu serah terima fisik Satuan Rumah Susun Pluit Sea View kepada konsumen.

Wanprestasi dapat terjadi disebabkan oleh dua hal, yaitu:

1) Karena kesalahan, baik karena kesengajaan ataupun karena kelalaian,

2) Karena keadaan memaksa (force majour), kejadian yang terjadi di luar kemampuannya.

Menilik dari kasus perjanjian jual beli Apartemen Pluit Sea View, wanprestasi yang dilakukan oleh oleh developer yaitu PT. Binakarya Bangun Propertindo adalah suatu kelalaian. Ingkar janji (wanprestasi) akan mengakibatkan timbulnya kerugian bagi pihak yang berhak atas prestasi tersebut. Developer tidak menyerahkan property yang dibeli oleh konsumen yang menjadi haknya sesuai dengan waktu yang dijanjikan merupakan salah satu bentuk ingkar janji. Dalam perjanjian sangat dimungkinkan banyak penyebabnya seperti kesulitan keuangan, 
Volume 2 Nomor 2, Desember 2019

E-ISSN : 2655-7347

kesulitan ijin, atau bahkan tidak ada itikad baik dari developer untuk memenuhi prestasinya.

Wanprestasi yang dilakukan oleh developer ini berakibat hukum bagi developer itu sendiri, yaitu tanggung jawab secara hukum atas apa yang telah diperbuatnya. Tanggung jawab adalah kewajiban menanggung segala sesuatunya bila terjadi apa-apa boleh dituntut, dipersalahkan, dan diperkarakan. Dalam kamus hukum, tanggung jawab adalah suatu keseharusan bagi seseorang untuk melaksanakan apa yang telah diwajibkan kepadanya.

Dalam hukum perdata, tanggung jawab pihak yang melakukan wanprestasi diwujudkan dalam bentuk pemberian ganti rugi kepada pihak yang dirugikan, sebagaimana pendapat Moegni Djojodirjo bahwa ganti rugi dalam hukum perdata dapat timbul dikarenakan wanprestasi akibat dari suatu perjanjian. ${ }^{8)}$

Dalam Pasal 1239 dan Pasal 1243 KUHPerdata disebutkan kerugian (yang harus diganti) meliputi tiga komponen yaitu Biaya (yang telah dikeluarkan), Rugi (kerugian yang diderita), dan Bunga (keuntungan yang diharapkan atau bunga). Ganti rugi yang diberikan kepada konsumen karena kesalahan pelaku usaha juga diatur dalam Pasal 10 Undang-Undang Nomor 8 tahun 1999 tentang Perlindungan Konsumen, yang berbunyi:

1) Pelaku usaha beratanggung jawab memberi ganti rugi atas kerusakan, pencemaran, dan/atau kerugian konsumen akibat menggunakan barang yang dihasilkan atau diperdagangkan.

2) Ganti rugi dapat berupa pengembalian uang atau penggantian barang dan/atau jasa yang sejenis atau setara nilainya, perawatan kesehatan atau pemberian santunan sesuai ketentuan undang-undang yang berlaku.

${ }^{7}$ Andi Hamzah, Kamus Hukum, (Indonesia: Ghalia), 2005.

8) M.A. Moegni Djojodirjo, Perbuatan Melawan Hukum, Cetakan ke-1, (Jakarta: Pradnya Paramita, 1979), hal. 11. 
3) Pemberian ganti rugi dilakukan dalam waktu 7 hari setelah tanggal transaksi.

4) Pemberian ganti rugi pada ayat 1 dan 2 tidak menutup kemungkinan adanya tuntutan pidana berdasar pembuktian lenih lanjut.

5) Ketentuan sebagaimana yang dimaksud dalam ayat 1 dan ayat 2 tidak berlaku bila pelaku usaha dapat membuktikan bahwa kesalahan tersebut merupakan kesalahan konsumen.

Dalam perjanjian jual beli (PPJB) Apartemen Pluit Sea View antara developer dan konsumen disebutkan bahwa: setelah pembeli melakukan pembayaran maka pihak pertama (developer) melakukan pembangunan dan penyerahan sebagaimana yang tercantum dalam pasal 6 PPJB, yaitu sebagai berikut:

1) Melaksanakan pembangunan satuan rumah susun sesuai gambar denah dan ketetapan peraturan perundang-undangan yang berlaku.

2) Pihak pertama Melakukan penyerahan fisik secara bertahap atas Pluit Sea View untuk Tower Ibiza A dimulai bulan Maret 2016, Tower Ibiza B dimulai bulan April 2016 dengan toleransi 145 (seratus empat puluh lima) hari kerja, kecuali:

3) Selama jangka waktu tersebut terjadi hal-hal yang berada di luar kekuasaan pihak pertama atau alasan force majeur.

4) Pihak kedua belum memenuhi semua kewajibannya.

5) Adanya peraturan atau kebijakan pemerintah yang menyebabkan keterlambatan dan /atau terhentinya pembangunan Pluit Sea View.

6) Apabila dalam waktu 7 hari setelah tanggal pemberitahuan untuk serah terima Sarusun Milik ternyata pihak kedua dan/atau kuasanya tidak datang dan/atau tidak menandatangani Berita Acara Serah Terima karena sebab/alasan apapun, maka pihak kedua dianggap menyetujui bahwa penyerahan Sarusun Milik telah dilakukan dan dalam hal demikian bukti pengiriman surat pemberitahuan untuk 
melakukan serah terima Sarusun Milik dianggap merupakan bukti yang cukup bahwa serah terima Sarusun Milik telah dilakukan pada hari ke7 setelah surat pemberitahuan itu disampaikan. Pihak kedua dengan ini memberikan kuasa kepada pihak pertama untuk menandatangani berita acara serah terima Sarusun Milik dan pihak kedua dianggap bersedia menerima baik penyerahan tersebut pada tanggal yang telah ditetapkan.

7) Terhitung sejak tanggal penandatanganan dan/atau tanggal serah terima Sarusun Milik, maka segala, setiap dan seluruh resiko serta kewajiban termasuk iuran terkait kewajiban pihak kedua, pihak pertama tidak lagi bertanggung jawab sepanjang mengenai hal tersebut.

8) Apabila pihak pertama telah siap menyerahkan Sarusun Milik sebelum batas waktu fisik penyerahan sebagaimana yang disebutkan dalam ayat 2 huruf a di atas, maka pihak pertama akan memberitahukan hal tersebut kepada pihak kedua.

9) Apabila pihak pertama tidak melakukan serah terima pada tanggal penyerahan sementara pihak kedua telah membayar lunas seluruh kewajiban pembayarannya, maka pihak pertama akan dikenakan denda keterlambatan sebesar $1 \% 0$ (satu permil) per hari dengan maksimal denda sebesar 3\% dari harga pengikatan.

10) Jika pihak pertama telah menyelesaikan Sarusun Milik sedangkan pihak kedua telah membayar kepada pihak pertama sebesar:

a. Lebih dari 50\% dari harga pengikatan berikut denda-denda dan kewajiban pembayaran lain yang terhutang (kalau ada), dan

b. Premi asuransi bangunan

Sesuai dengan pasal 6 ayat (4) PPJB di atas yang menyebut apabila pihak pertama tidak melakukan serah terima pada tanggal penyerahan (wanprestasi) sementara pihak kedua telah membayar lunas seluruh kewajiban pembayarannya, maka pihak pertama akan dikenakan denda keterlambatan sebesar $1 \%$ (satu permil) per hari dengan maksimal denda sebesar 3\%o dari harga pengikatan. Pasal ini menjadi dasar bagi konsumen untuk menuntut tanggung jawab developer apabila 
melakukan wanprestasi yaitu tidak melakukan serah terima pada tanggal penyerahan padahal konsumen telah membayar lunas.

Tanggung jawab developer dalam hal ini adalah pemberian ganti rugi kepada konsumen, dan besarnya ganti rugi yang dapat dituntut oleh konsumen satuan rumah susun atau atau apartemen Pluit Sea View adalah seperti yang tertuang dalam Pasal 6 PPJB yaitu dikenakan denda keterlambatan sebesar $1 \% 0$ (satu permil) per hari dengan maksimal denda sebesar 3\% dari harga pengikatan. Namun demikian ganti rugi ini tidak menghapuskan tanggung jawab utama developer yaitu melakukan serah terima Apartemen Pluit Sea View pada tanggal penyerahan yang telah disepakati. Karena tanggung jawab berarti kewajiban seseorang atau suatu pihak untuk menanggung segala akibat apabila terjadi sesuatu yang menyebabkan kerugian pihak lainnya atas kesalahan yang disengaja ataupun tidak sengaja boleh dituntut, dipersalahkan, dan diperkarakan. Tanggung jawab juga merupakan suatu keseharusan bagi seseorang untuk memenuhi kewajiban apa yang telah disepakati olehnya dalam perjanjian.

Dalam kasus wanprestasi developer Apartemen Pluit Sea View, pihak developer tidak atau belum memenuhi tanggungjawabnya seperti yang tertuang dalam PPJB. Pada Pasal 6 angka (2) PPJB No.243/PPJBPSV/BBP/X/2014 yang menyebutkan pihak pertama melakukan penyerahan fisik secara bertahap atas Pluit Sea View untuk Tower Ibiza A dimulai bulan Maret 2016 dan Tower Ibiza B dimulai bulan April 2016 dengan toleransi 145 (seratus empat puluh lima), dan angka (4) yang menyebutkan apabila pihak kedua telah membayar lunas seluruh kewajiban pembayarannya sesuai dengan yang telah tertulis didalam perjanjian tetapi pihak pertama tidak dapat melakukan serah terima pada tanggal penyerahan (wanprestasi), maka pihak pertama akan dikenakan denda keterlambatan sesuai yang tertulis di PPJB yaitu sebesar 1/\%0 (satu per mil) per hari dengan maksimal denda sebesar 3\% dari harga pengikatan. 
Pihak pertama yaitu developer tidak melakukan serah terima Apartemen Pluit Sea View pada waktu yang telah diperjanjikan bahkan setelah toleransi 145 (seratus empat puluh lima), dan tidak membayar denda atas keterlambatan sesuai yang tertulis di PPJB yaitu sebesar $1 / \%_{0}$ (satu per mil) per hari dengan maksimal denda sebesar 3\% dari harga pengikatan kepada konsumen. Dengan demikian maka dapat dikatakan bahwa developer Apartemen Pluit Sea View tidak memenuhi tanggungjawabnya sama sekali kepada konsumen. Atau dengan kata lain developer Apartemen Pluit Sea View tidak bertanggungjawab.

\section{Perlindungan Hukum terhadap Konsumen Pluit Sea View}

Perlindungan hukum merupakan suatu perlindungan yang bersifat preventif (pencegahan) maupun dalam bentuk yang bersifat represif (pemaksaan), yang diberikan kepada subyek hukum sesuai dengan aturan hukum, baik yang secara tertulis maupun tidak tertulis dengan tujuan untuk menegakkan peraturan hukum. Perlindungan hukum memberikan kepastian dan menjamin untuk seseorang mendapatkan hak dan kewajibannya sehingga seseorang tersebut merasa aman.

Perlindungan konsumen sebenarnya sudah terjadi dimulai sejak adanya niat pelaku usaha untuk menawarkan produknya kepada calon konsuen dan berlanjut pada masa terjadinya transaksi. Intinya perlindunggan konsumen timbul sejak akan melakukan transaksi, ketika melakukan transaksi dan ketika memenuhi transaksi tersebut. Perlindungan konsumen pada masa pra transaksi menimbulkan hak calon konsumen dan menimbulkan kewajiban pelaku usaha untuk memenuhi hak-hak konsumen.

Hak Konsumen diatur didalam Pasal 4 Undang-Undang Perlindungan Konsumen yaitu konsumen mempunyai ha katas keselamatan, keamanan dan kenyamanan dalam mengkonsumsi atau menggunakan barang dan/atau jasa. Konsumen juga berhak untuk 
Volume 2 Nomor 2, Desember 2019

E-ISSN : 2655-7347

memilih barang dan/atau jasa dan mendapatkannya sesuai dalam perjanjian serta mendapatkan informasi yang jujur, jelas dan benar mengenai kondisi dan jaminan barang dan/atau jasa. Konsumen juga berhak untuk menyampakan keluhan atas barang dan/atau jasa yang diperjanjikan, mendapatkan perlindungan, advokasi serta upaya penyelesaian sengketa dengan patut. Diperlakukan dengan benar dan tidak mendapatkan sikap diskriminatif dari pihak penjual. Dalam pasal ini juga mengatur mengenai hak konsumen untuk mendapatkan kompensasi, ganti rugi, atau penggantian apabila tidak sesuai dengan yang diperjanjikan.

Hak-hak konsumen di atas berguna untuk melindungi kepentingan konsumen, sebagaimana yang tercantum di dalam tujuan dari perlindungan konsumen yaitu mengangkat harkat dan martabat konsumen. Konsumen hendaknya sadar betul akan hak-haknya dan pelaku usaha hendaknya memperhatikan perbuatan-perbuatan apa saja yang dilarang menurut Undang-Undang Perlindungan Konsumen sehingga tidak melakukan pelanggaran hak-hak konsumen.

Adanya hak-hak konsumen menimbulkan konsekuensi bagi pelaku usaha berupa kewajiban-kewajiban seperti yang disebutkan dalam Pasal 7 Undang-undang Perlindungan Konsumen, yaitu:

Kewajiban pelaku usaha atau developer diatur dalam Pasal 7 UU Perlindungan Konsumen. Bahwa pelaku usaha (developer) berkewajiban untuk bertikitad baik dalam melakukan kegiatan usahanya serta memberikan segala informasi mengenai jaminan dan kondisi barang dan/atau jasa dengan jujur, jelas dan benar berikut dengan penjelasan tentang perawatan, perbaikan, dan penggunaan barang yang diperjanjikan. Memberikan kesempatan kepada konsumen (pembeli) untuk mencoba dan/atau menguji barang dan/atau jasa tersebut serta memberikan jaminan atas barang dan/atau jasa tersebut dan telah sesuai dengan ketentuan standar mutu yang berlaku. Dalam pasal ini juga mengatur bahwa pelaku usaha (developer) harus melayani 
Volume 2 Nomor 2, Desember 2019

E-ISSN : 2655-7347

konsumen (pembeli) dengan jujur dan benar tanpa adanya tindakan diskriminatif serta memberikan komepensasi, ganti rugi dan/atau penggantian apabila barang dan /atau jasa yang diterima atau dimanfaatkan tidak sesuai dengan perjanjian.

Perlindungan konsumen harus dipenuhi dalam semua bentuk pembelian barang/jasa, apalagi dalam pembelian Apartemen Pluit Sea View yang memiliki harga tinggi dan memiliki nilai ekonomi yang tinggi pula. Perlindungan konsumen dalam jual beli Apartemen Pluit Sea View sebenarnya sudah ada, yang dibuktikan dengan adanya Perjanjian Perikatan Jual Beli (PPJB) antara developer dengan konsumen yang dibuat oleh akta notaris. Perjanjian jual beli tersebut melegalisasi transaksi antara developer dan konsumen, yang memiliki kekuatan hukum dan merupakan bukti otentik bagi konsumen sebagai pembeli bahwa dia berhak mendapatkan barang/jasa sesuai dengan kondisi yang disepakati dalam perjanjian tersebut. PJJB sebagai bukti otentik pembelian barang/jasa dan memiliki kekuatan hukum tersebut, dapat digunakan sebagai dasar bagi konsumen untuk melakukan gugatan kepada penjual apabila tidak memenuhi hak-hak konsumen atau melakukan pelanggaran atas perjanjian yang telah disepakati.

Oleh karena itu sebelum melakukan penandatanganan perjanjian jual beli sebagai tanda kesepakatan atau persetujuan butir-butir yang diatur dalam perjanjian, konsumen meminta penjelasan terlebih dahulu kepada penjual tentang semua hal yang ingin diketahui terutama terkait kondisi barang, harga, dan sanksi atau denda baik dari pihak penjual atau pembeli apabila melakukan perbuatan yang dianggap melanggar perjanjian. Hak ini merupakan hak konsumen dan kewajiban penjual sebagaimana yang tercantum dalam Pasal 7 ayat (2) bahwa penjual (developer) berkewajiban untuk memberikan informasi yang jujur, jelas, dan benar mengenai jaminan dan kondisi barang dan/atau jasa serta memberi penjelasan mengenai pemeliharaan, perbaikan, dan penggunaan. 
Volume 2 Nomor 2, Desember 2019

E-ISSN : 2655-7347

Namun pada kenyataannya, tidak banyak konsumen yang meminta informasi dan keterangan yang sejelas-jelasnya kepada penjual tentang barang yang akan dibeli serta pasal-pasal yang termuat dalam perjanjian jual beli. Kondisi ini menimbulkan kerugian bagi konsumen, karena pasal-pasal yang ada dalam perjanjian tersebut ternyata lebih menguntungkan penjual/developer dan konsumen tidak berdaya. Misalnya pada pasal 4 PPJB yang secara rinci menyebutkan:

1. Segala akibat hukum yang timbul karena pembayaran yang dilakukan tidak menurut ketentuan dalam perjanjian merupakan resiko dan tanggung jawab pihak kedua (konsumen).

2. Jika pihak kedua lalai atau tidak membayar angsuran dan/atau kewajiban pembayaran lainnya pada waktu dan jumlah yang ditentukan, maka pihak kedua dikenakan denda keterlambatan sebesar $1 \% 0$ (permil) perhari keterlambatan yang dihitung dari jumlah angsuran maupun kewajiban pembayaran lainnya yang terlambat atau kurang pembayarannya. Termasuk pengertian keterlambatan/kelalaian adalah kurang bayar atau tidak dapat diuangkannya atau dipindahbukukannya cek bilyet/giro yang diberikan oleh pihak kedua pada saat jatuh temponya dan dihitung sejak hari jatuh tempo tersebut.

Ketentuan pasal 4 PPJB di atas menunjukkan perjanjian tersebut memaksa konsumen untuk memenuhi semua hal yang diinginkan oleh penjual, dan konsumen tidak memiliki bargaining power. Hal ini seperti yang diungkapkan oleh salah seorang konsumen Apartemen Pluit Sea View di tower Beliza yang pernah melakukan komplain kepada manajemen PT Binakarya Bangun Propertindo karena developer tidak memenuhi haknya, tetapi merasa percuma karena PPJB memberatkan pihak pembeli. ${ }^{9)}$ Kondisi ini menunjukkan bahwa

${ }^{9)}$ Andhikatamaaa. 2018. Komunitas calon penghuni apartemen pluit Sea View. https://www.kaskus.co.id/thread/51132dd2562acf7e62000005/komunitas-calon-penghuni -pluitsea-view-apartemen/104, diakses tanggal 7 November 2019. 
developer tidak memberikan perlindungan kepada konsumennya. Dalam keadaan seperti ini maka sah bagi konsumen untuk mencari perlindungan hukum melalui pengadilan, menggunakan PPJB sebagai dasar pengajuan permohonan kepada pengadilan.

Menurut peneliti, perlindungan konsumen pembeli Apartemen Pluit Sea View masih sangat lemah. Hal ini dikarenakan sistem pembayaran dan pasal-pasal ketentuan tentang pembayaran Apartemen cukup memberatkan konsumen dan belum berpihak kepada konsumen. Misalnya saja pada klausul 2 Pasal 4 PPJB yang berbunyi “Termasuk pengertian keterlambatan/kelalaian adalah kurang bayar atau tidak dapat diuangkannya atau dipindahbukukannya cek bilyet/giro yang diberikan oleh pihak kedua pada saat jatuh temponya dan dihitung sejak hari jatuh tempo tersebut".

Di sisi lain pihak developer tidak memenuhi kewajibannya yaitu melakukan serah terima sesuai dengan tanggal yang diperjanjikan bahkan setelah diberikan waktu perpanjangan selama 30 hari kalender. Kenyataan ini merupakan bukti nyata apabila PT Binakarya Bangun Propertindo selaku developer dan penjual Apartemen Pluit Sea View tidak memberikan perlindungan kepada konsumennya. Namun pihak developer tidak memberikan konfirmasi kepada konsumen yang tidak kunjung mendapatkan haknya tersebut. Dengan demikian maka langkah tepat yang diambil konsumen adalah berupaya untuk mendapatkan perlindungan hukum kepada pengadilan dengan mengajukan gugatan seperti yang dilakukan oleh beberapa konsumen. Salah satunya adalah konsumen yang bernama $\mathrm{Ng}$ Hui Hui yang mengajukan gugatan kepada Pengadilan Negeri Jakarta.

Pada kasus perjanjian jual beli Apartemen Pluit Sea View, dapat dikatakan bahwa konsumen tidak mendapatkan perlindungan konsumen dari developer/penjual karena tidak mendapatkan hakhaknya seperti yang diperjanjikan dan pihak developer/penjual juga tidak melakukan upaya apapun termasuk memberikan penjelasan 
Volume 2 Nomor 2, Desember 2019

E-ISSN : 2655-7347

kepada konsumen mengapa belum atau tidak dilakukan serah terima bangunan pada waktu yang telah diperjanjikan. Salah satu cara yang dapat dilakukan oleh konsumen agar konsumen Apartemen Pluit Sea View mendapatkan perlindungan adalah melalui jalur hukum yaitu mengajukan pengajuan ke pengadilan.

\section{PENUTUP}

\section{A. Kesimpulan}

Berdasarkan pembahasan yang telah diuraikan dalam bab sebelumnya, maka diperoleh kesimpulan sebagai berikut:

1. Tanggung jawab pihak penjual Apartemen Pluit Sea View yaitu PT. Binakarya Bangun Propertindo (developer) kepada pembeli/konsumen sudah tertulis dalam Pasal 6 PPJB No.243/PPJB-PSV/BBP/X/2014 yaitu developer melakukan penyerahan fisik pada tanggal penyerahan dengan toleransi 145 (seratus empat puluh lima), dan apabila developer tidak dapat melakukan serah terima tersebut maka developer harus membayarkan denda keterlambatan yaitu sebesar 1/\%0 (satu per mil) per hari dengan maksimal denda sebesar 3\% dari harga pengikatan. Faktanya, developer Apartemen Pluit Sea View tidak memenuhi tanggung jawabnya yaitu tidak melakukan serah terima unit Apartemen Pluit Sea View kepada konsumen yang sudah lunas pembayarannya, dan tidak membayar denda keterlambatan serah terima sebesar $1 / \%_{0}$ (satu per mil) per hari dengan maksimal denda sebesar 3\% dari harga pengikatan kepada konsumen.

2. Perlindungan konsumen Apartemen Pluit Sea View adalah lemah, konsumen tidak memiliki bargaining power. Perjanjian Perikatan Jual Beli (PPJB) antara konsumen dan penjual mendudukkan konsumen pada posisi yang lemah atau tidak berdaya, karena Perjanjian Perikatan Jual Beli (PPJB) belum memiliki kekuatan hukum sampai dilakukannya akta jual beli (AJB). Namun demikian PPJB dapat digunakan sebagai 
Volume 2 Nomor 2, Desember 2019

E-ISSN : 2655-7347

dasar bagi konsumen untuk mengajukan guguatan ke pengadilan sebagai upaya mendapat perlindungan hukum formil dan materiil.

\section{B. Saran}

Berdasarkan kesimpulan di atas, maka peneliti memberikan beberapa saran yang dapat digunakan sebagai masukan atau direkomendasikan kepada pihak-pihak yang terkait. Saran tersebut antara lain adalah sebagai berikut:

1. Bagi developer hendaknya bertanggungjawab dengan memenuhi hakhak konsumen seperti yang telah disepakati dalam PPJB, dan informasi yang benar, jujur, dan jelas kepada konsumen.

2. Bagi konsumen hendaknya lebih berhati-hati dalam membeli rumah susun atau apartemen, dan kritis terhadap perjanjian jual beli yang akan disepakati dengan meminta informasi atau keterangan yang sejelasjelasnya tentang pasal-pasal yang tertuang dalam PPJB agar tidak dirugikan.

3. Pemerintah hendaknya melakukan pengawasan yang intensif kepada para developer, mengingat banyaknya kasus penipuan atau pelanggaran yang dilakukan oleh developer untuk melindungi konsumen.

\section{DAFTAR PUSTAKA}

\section{A. Buku}

Hamzah, Andi. Kamus Hukum, (Indonesia: Ghalia, 2005).

Subekti, R. Hukum Perjanjian. Cetakan ke-21. (Jakarta: Internusa, 2005).

Prodjodikoro, Wirjono. Asas-Asas Hukum. (Bandung: 1986).

\section{B. Website}

Andhikatama. Komunitas calon penghuni apartemen Pluit Sea View. https://www.kaskus.co.id/thread/51132dd2562acf7e62000005/ko 
Natalia Salim \& Endang Pandamdari TANGGUNG JAWAB DEVELOPER TERHADAP KONSUMEN AKIBAT WANPRESTASI DALAM PENYERAHAN UNIT APARTEMEN PLUIT SEA VIEW BERDASARKAN PERJANJIAN PENGIKATAN JUAL BELI

Volume 2 Nomor 2, Desember 2019

E-ISSN : 2655-7347

munitas-calon-penghuni -pluitsea-view-apartemen/104, diakses tanggal 7 November 2019.

Wijaya, Andi. Sudah Lewat Waktunya, Apartemen Pluit Sea View belum

Serah Terima, Senin 10 Juli 2017. https://news.detik.com/suarapembaca/3553807/ sudah-lewat-waktunya-apartemen-pluit-seaview-belum-serah-terima, diakses tanggal 7 November 2019.

\section{Undang-Undang}

Indonesia. Kitab Undang-Undang Hukum Perdata.

.Undang-Undang Republik Indonesia Nomor 8 Tahun 1999 tentang Perlindungan Konsumen.

Undang-Undang Republik Indonesia Nomor 20 TAHUN 2011 tentang Rumah Susun. 